\title{
Prostate adenocarcinoma with a rectal metastasis
}

\author{
Nwabundo Nwankwo, ${ }^{1}$ Aibek E Mirrakhimov, ${ }_{1}^{1}$ Teresita Zdunek, ${ }^{2}$ Nora Bucher ${ }^{1}$
}

1 Department of Internal Medicine, Saint Joseph Hospital, Chicago, Illinois, USA ${ }^{2}$ Department of Pathology, Saint Joseph Hospital, Chicago, Illinois, USA

\section{Correspondence to} Dr Aibek E Mirrakhimov, amirrakhimov1@gmail.com
To cite: Nwankwo N, Mirrakhimov AE, Zdunek T, et al. BMJ Case Rep Published online: [please include Day Month Year doi:10.1136/bcr-2013009503

\section{DESCRIPTION}

A 69-year-old man with a medical history of HIV infection and prostate cancer presented to our practice complaining of lower abdominal pain and rectal bleeding. Prostate cancer was diagnosed in 1990, for which the patient underwent radiation therapy, bilateral orchiectomy and was managed with flutamide for several years. Twelve years after the initial diagnosis, he underwent prostate cryoablation. However, prostate-specific antigen continued to rise from 5.98 to 107.43 over a span of 6 months.

CT scan of the abdomen and pelvis revealed retroperitoneal and right iliac adenopathy, a nodal mass at the level of kidneys measuring $3.8 \times 2.4 \mathrm{~cm}$. The patient had a colonoscopy and a $3 \mathrm{~cm}$ oozing soft mass was found at the rectal verge (figure 1). Biopsy was done, which stained positive for prostatic acid phosphatase and CDX2 consistent with poorly differentiated adenocarcinoma metastatic from prostate (figure 2). ${ }^{12}$

Prostate cancer is the second most common cancer in men with metastasis commonly occurring in the bones. ${ }^{3}$ On rare occasions, it metastasises to the rectum. ${ }^{4}$ The anatomic route can be via lymphatic drainage, since prostate and rectum share a common route, and/or via direct invasion of the rectum by the prostate cancer and/or via metastatic implant while performing a needle biopsy of the prostate. $^{5-7}$

In conclusion, infiltration of the rectum by prostate cancer cells presents with abdominal pain and rectal bleeding; physicians should regularly assess for gastrointestinal symptoms and perform regular rectal examinations in patients with prostate cancer.

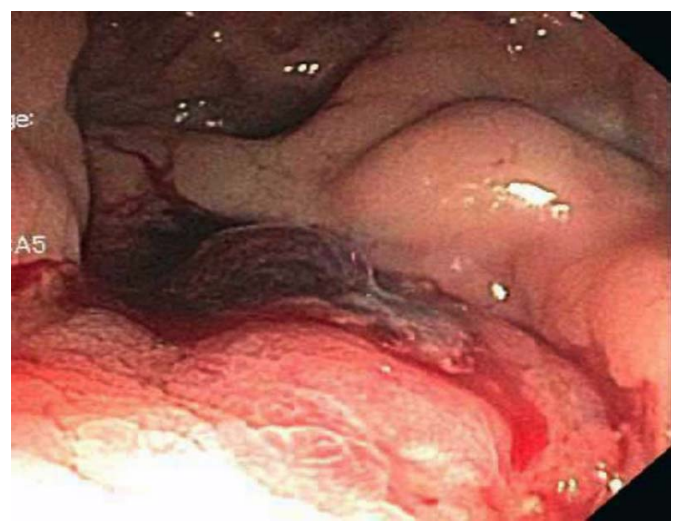

Figure 1 Colonoscopy showing a soft oozing mass.

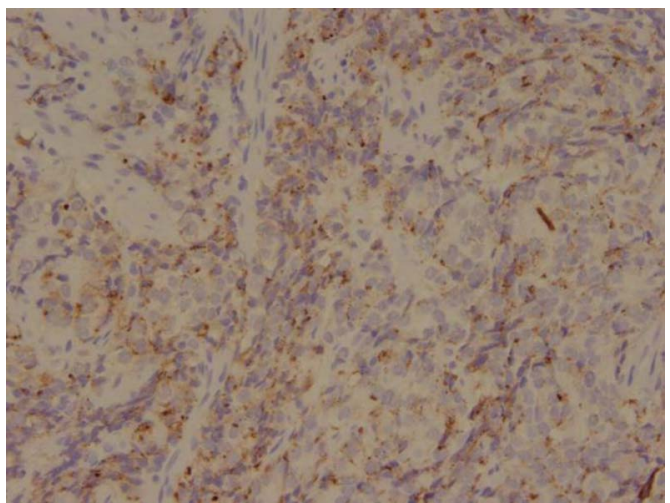

Figure 2 Rectal biopsy consistent with metastatic prostate cancer.

\section{Learning points}

Prostate cancer is the second most common cancer in men.

- Bones are the most common site for prostate cancer metastases.

- New onset abdominal pain and rectal bleeding in a patient with prostate cancer needs for work for a metastatic lesion to the rectum from the prostate.

\section{Competing interests None.}

Patient consent Obtained.

Provenance and peer review Not commissioned; externally peer reviewed.

\section{REFERENCES}

1 Herawi M, De Marzo AM, Kristiansen G, et al. Expression of CDX2 in benign tissue and adenocarcinoma of the prostate. Hum Pathol 2007;38:72-8.

2 Kirschenbaum A, Liu XH, Yao S, et al. Prostatic acid phosphatase is expressed in human prostate cancer bone metastases and promotes osteoblast differentiation. Ann N Y Acad Sci 2011;1237:64-70.

3 American Cancer Society. Cancer facts and figures 2013. Atlanta: American Cancer Society, 2013.

4 Abbas TO, Al-Naimi AR, Yakoob RA, et al. Prostate cancer metastases to the rectum: a case report. World J Surg Oncol 2011;9:56.

5 Murray SK, Breau RH, Guha AK, et al. Spread of prostate carcinoma to the perirectal lymph node basin: analysis of 112 rectal resections over a 10-year span for primary rectal adenocarcinoma. Am J Surg Pathol 2004;28:1154-62.

6 Vaghefi H, Magi-Galluzzi C, Klein EA. Local recurrence of prostate cancer in rectal submucosa after transrectal needle biopsy and radical prostatectomy. Urology 2005;66:881.

7 Lane Z, Epstein Jl, Ayub S, et al. Prostatic adenocarcinoma in colorectal biopsy: clinical and pathologic features. Hum Pathol 2008;39:543-9. 
Copyright 2013 BMJ Publishing Group. All rights reserved. For permission to reuse any of this content visit http://group.bmj.com/group/rights-licensing/permissions.

BMJ Case Report Fellows may re-use this article for personal use and teaching without any further permission.

Become a Fellow of BMJ Case Reports today and you can:

- Submit as many cases as you like

- Enjoy fast sympathetic peer review and rapid publication of accepted articles

- Access all the published articles

- Re-use any of the published material for personal use and teaching without further permission

For information on Institutional Fellowships contact consortiasales@bmjgroup.com

Visit casereports.bmj.com for more articles like this and to become a Fellow 